carries small pebbles with it. It is not sufficient merely to plant grass to arrest the travelling sand dunes. The best way seems to be to plant suitable trees. In a paper by Dr. R. M. Gorrie published in the Empire Forestry Journal $(14,1$; 1935) a scheme for enlarging farming shelterbelts so that they extend from the Canadian border down to Texas is described. Thousands of farmers have accepted aid from the Department of Agriculture, and the belts that have been constructed have greatly increased the comfort in which they live. In the arid Middle West, fruit growing becomes a possibility only when a shelterbelt is made. Dr. Gorrie says that the American scheme consists in multiplying the existing small windbreaks until about 2,500 square miles of forest has been planted. The layout of the belts is determined by the worst wind, and a width of about 150 feet is usually employed. As a means of relieving unemployment the scheme proved useful. In the same number of the Journal Mr. C. J. W. Pitt-Schenkel describes windbreaks in Tanganyika territory. A series of windbreaks are being planted across part of the country to check erosion and to protect the grass from being dried up rapidly by the prevailing wind.

\section{Radium Deposits in North-West Canada}

IN Sands, Clays and Minerals of June 1935, published by the Westmoor Laboratory, Chatteris, England, Dr. H. S. Spence, of the Canadian Department of Mines, gives an authoritative and wellillustrated account of the discovery, occurrence and exploitation of the pitchblende deposits found by Gilbert Labine in 1930 on the eastern shore of Great Bear Lake. Work to date has demonstrated the existence of extremely rich ore in three veins. Three months' operation of the Eldorado Company's mill showed that the raw material is of exceptionally high grade, the best being equivalent to a radium content of one gram per $6 \frac{1}{2}$ tons. Occurrences of native silver add to the value of the deposits, some of the ore assaying up to $9,000 \mathrm{oz}$. of silver per ton. In veins 1 and 3 and in part of vein 2 the pitchblende was originally deposited in botryoidal crusts which were later brecciated and re-cemented by quartz. In the other part of vein 2 the gangue material is not silica, but carbonates of manganese, iron and lime, together with barytes. It is this section of vein 2 which is characterised by native silver, in flakes and leaves occurring in both pitchblende and gangue.

OTHer discoveries of pitchblende have been made in this region; one immediately to the east of La Bine Point; another ten miles to the south-east; and another at Beaverlodge Lake, a hundred miles to the south. The last of these discoveries was made by smell! Indians had noticed a peculiar smell when camping at La Bine Point. In the winter of 1934 when the ground was covered with snow, they showed a prospector a spot on Beaverlodge Lake where they had noticed a similar smell. The snow was cleared and a pitchblende vein was disclosed beneath. An official town site has now been established at Cameron Bay, just south of La Bine Point. The Eldorado
Company's radium refinery is at Port Hope, fifty miles east of Toronto, 4,000 miles from the mines. Up to June 1934, the plant had isolated $5 \frac{1}{2}$ grams of radium from 58 tons of pitchblende, together with 35,000 pounds of uranium compounds and $30,000 \mathrm{oz}$. of silver.

\section{Reduction in Price of German Books and Periodicals}

As a result of comments upon the excessive cost of German periodicals recently made in Great Britain and the United States, German publishers, two years ago, reduced their prices by 20 per cent. (See article by Dr. W. Bonser, Librarian of the University of Birmingham, NATURE of July 1, 1933, p. 34, and again of October 7,1933 , p. 540.) Unfortunately this reduction was at once counterbalanced by the fall in the value of the pound sterling. The German publishers are, however, making a further reduction, so that now the benefit will be appreciable. We are informed that: "From September 9th, 1935, there will be a discount of 25 per cent on the published prices of all new books originating from and published in Germany, on music and on all graphical instructive material, on subscriptions to periodicals, provided they were not charged before that date". The reductions will make a great difference to all university and society libraries; for example, the physiological Berichte, formerly costing 6 vols. at RM. 68 will now be at RM. 51-a saving of about $£ 8$ a year.

\section{Recent Earthquakes}

WE have received from Kew Observatory a notice of a violent earthquake recorded there at $14 \mathrm{~h} .16 \mathrm{~min}$. on September 11. The epicentre is estimated to have been in about lat. $43^{\circ} \mathrm{N}$., long. $146^{\circ} \mathrm{E}$., or about thirty miles off the south-east coast of the northern island of Hokkaido. This point is about thirty miles to the north of the epicentre of the destructive earthquake of April 25, 1843, after which seawaves $16 \mathrm{ft}$. high swept over the coast, and about eighty miles north-north-east of that of the less destructive earthquake of March 22, 1894, which was followed by seawaves about $5 \mathrm{ft}$. high on the coast of Hokkaido and $10 \mathrm{ft}$. high at Kamaisi on the east coast of Japan. A very violent earthquake was recorded at the Observatory at $2 \mathrm{~h} .8 \mathrm{~min} .13 \mathrm{sec}$. G.M.T., on September 20. The epicentre is estimated to have been 7,500 miles away, probably under the Pacific Ocean near the Mariamme Islands.

\section{String-Figures}

Kathleen Haddon (Mrs. O. H. T. Rishbeth), unquestionably our foremost expert in the study of the string-figure, has published a selection of these ingenious diversions for the use of beginners ("String Games for Beginners", Heffer and Sons, Cambridge. $6 d$. net). Twenty-four figures given here will serve as an introduction to their endless variety, and afford those previously uninstructed some idea of their wide distribution in various parts of the world. Mrs. Rishbeth has drawn on her own material collected in New Guinea and Australia, on figures brought back by Dr. A. C. Haddon from the Torres Straits, and 